\title{
VÝVOJ TRHU ELEKTRONICKÝCH KOMUNIKÁCIÍ NA SLOVENSKU
}

\author{
Juraj Zachar ${ }^{1}$, Petra Kunertová ${ }^{2}$
}

\begin{abstract}
Abstrakt: Článok opisuje vývoj elektronických komunikácií na Slovensku. Oblast' elektronických komunikácií je na Slovensku rozdelená na tri čiastkové trhy: trh pevných sietí, trh mobilných sietí a trh širokopásmového prístupu. Spoločne tieto tri čiastkové trhy vytvárajú jednotný trh elektronických komunikácií, na ktorom pôsobia jednotliví prevádzkovatelia elektronických komunikačných sietí a poskytovatelia elektronických komunikačných služieb. V článku je tiež popísaný vývoj jednotlivých trhov elektronických komunikácií.
\end{abstract}

Kl'účové slová: elektronické komunikácie, účastnícka prípojka, širokopásmový prístup, mobilná siet', pevná siet'.

\section{Úvod}

Elektronické komunikačné siete a služby sú kl'účovým faktorom na ceste do informačnej spoločnosti a zároveň vytvárajú základné podmienky na prístup občanov a podnikov k moderným komunikačným siet’am a službám v rámci celosvetovej informačnej infraštruktúry. Možnost' využívat' kvalitné a dostupné komunikačné služby by mali mat' všetci občania, aby sa zabránilo ich vylúčeniu z informačnej spoločnosti. Sektor elektronických komunikácií možno považovat' za motor štrukturálnych zmien celého hospodárstva štátu.

Elektronické komunikácie sú pomerne novým pojmom, ktorý vznikol pri prebiehajúcej konvergencii sektorov telekomunikácií, médií a informačných technológií a nahradil dovtedy používaný termín telekomunikácie. Pojem elektronické komunikácie sa používa aj v terminológii celého súboru smerníc nového regulačného rámca elektronických komunikačných sietí a služieb Európskeho parlamentu a Rady európskych spoločenstiev.

\section{Trh elektronických komunikácií (EK)}

Elektronické komunikácie zabezpečujú výmenu alebo prenos informácií medzi konečným počtom užívatel'ov uskutočňovaných po elektronických komunikačných siet’ach. Konkrétna výmena alebo presun sa uskutočňuje prostredníctvom trhu EK. Trh elektronických komunikácií na Slovensku možno rozdelit' podl'a druhu pripojenia na tri základné trhy, ktoré sa môžu medzi sebou prelínat' a sú to:

$>$ Trh pevných sietí

$>$ Trh mobilných sietí

$>$ Trh širokopásmového prístupu

\footnotetext{
${ }^{1}$ Ing. Juraj Zachar., Žilinská univerzita v Žiline, Fakulta Prevádzky a ekonomiky dopravy a spojov, Katedra spojov, Univerzitná 1, 01026 Žilina, email: juraj.zachar@fpedas.uniza.sk

${ }^{2}$ Ing. Petra Kunertová, Žilinská univerzita v Žiline, Fakulta Prevádzky a ekonomiky dopravy a spojov, Katedra spojov, Univerzitná 1, 01026 Žilina, email: petra.kunertova@ @pedas.uniza.sk
} 


\section{Trh pevných sietí}

Pevná siet' je funkčne prepojená sústava prenosových systémov, prepájacích, smerovacích zariadení a iných prostriedkov umožňujúcich prenos signálov a informácií. Najvhodnejším ukazovatel'om vývoja trhu pevných sietí je absolútny počet účastníckych prípojok (UP) v pevnej sietí. Za posledné roky zaznamenávame neustály pokles účastníckych prípojok $\mathrm{v}$ pevnej sieti. Je to celosvetový trend, ktorý je spôsobený nahradzovaním pevnej verejnej telefónnej služby mobilnou službou. Dôkazom toho je dlhodobý nárast počtu aktívnych užívatel'ov mobilných sietí.

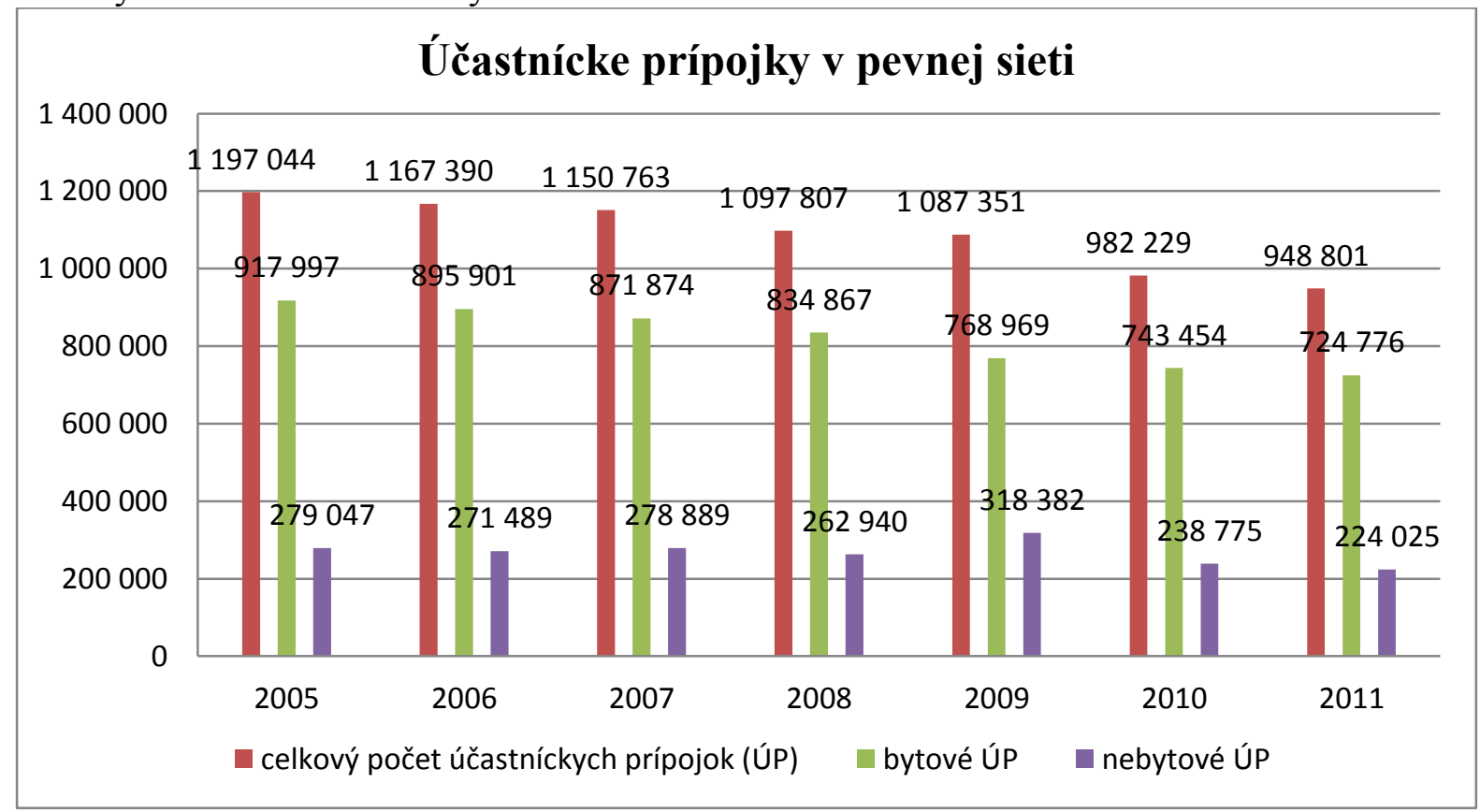

Obrázok 1: Vývoj účastníckych prípojok v pevnej sieti na Slovensku. (Zdroj: Elektronické komunikácie vybrané štatistické údaje [online]. [Citované 2012-7-23]. Dostupné na: http://www.telecom.gov.sk/files/statistika_vus/telekom/index.htm - vlastné spracovanie)

Ako si môžeme všimnút' na obrázku č.1, vývoj účastníckych prípojok (ÚP) od roku 2005 neustále klesá. Je to spôsobené hlavne narastajúcim trendom používania mobilných telefónov. Byt' zastihnutel'ný kdekol'vek a kedykol'vek je jedna z hlavných zákazníckych požiadaviek. Rýchlosti pripojenia na internet prostredníctvom mobilných telefónov sú porovnatel'né s ponukou pevných liniek, pričom v niektorých prípadoch ich aj prevyšujú. Preto pevné siete nemôžu konkurovat' mobilným siet'am v tejto zákazníckej požiadavke. Poklesu ÚP nezabránila ani možnost' vybrat' si pripojenie v pevnej sieti od viacerých poskytovatel'ov (dominantným poskytovatel'om je spoločnost' Slovak Telekom, a.s.). Od roku 2005 do roku 2011 sa znížil celkový počet ÚP o 248 243. Každoročný nižší počet zaznamenali aj bytové ÚP, ktorých celkový absolútny pokles početnosti za obdobie 6 rokov je 193 221. V súčasnosti operátori ponúkajú množstvo internetových služieb na pevných linkách, ale ani to nezabránilo každoročnému celkovému poklesu. Konkurenciou pre pevné linky na Slovensku sú okrem mobilov aj prevádzkovatelia káblovej televízie. Najväčšia spoločnost' na trhu UPC Slovensko, ponúka okrem možnosti pozerania televízie aj telefonovanie a internet. Preto s vel'kou pravdepodobnost'ou trend každoročného znižovania ÚP v pevnej sieti bude pokračovat' [1]. 


\section{Trh mobilných sietí}

Trh mobilných sietí predstavuje priestor, v ktorom vystupujú konkrétni mobilní operátori, poskytujúci služby a produkty zákazníkom. Z dôvodu neustáleho technologického rozvoja, najmä mobilných technológií, patrí mobilný trh $\mathrm{k}$ rýchlo expandujúcim a napredujúcim trhom na celom svete. Na slovenskom trhu mobilných sietí dominujú tri významné spoločnosti: Orange Slovensko a.s., Slovak Telekom a.s. a Telefónica Slovakia s.r.o. Najvhodnejším ukazovatel'om na popísanie vývoja tohto trhu, je vývoj absolútneho počtu SIM kariet, pretože tento počet vystihuje približne najpresnejší počet užívatel'ov jednotlivých mobilných koncových zariadení.

\section{Vývoj počtu SIM kariet v mobilnej sieti}

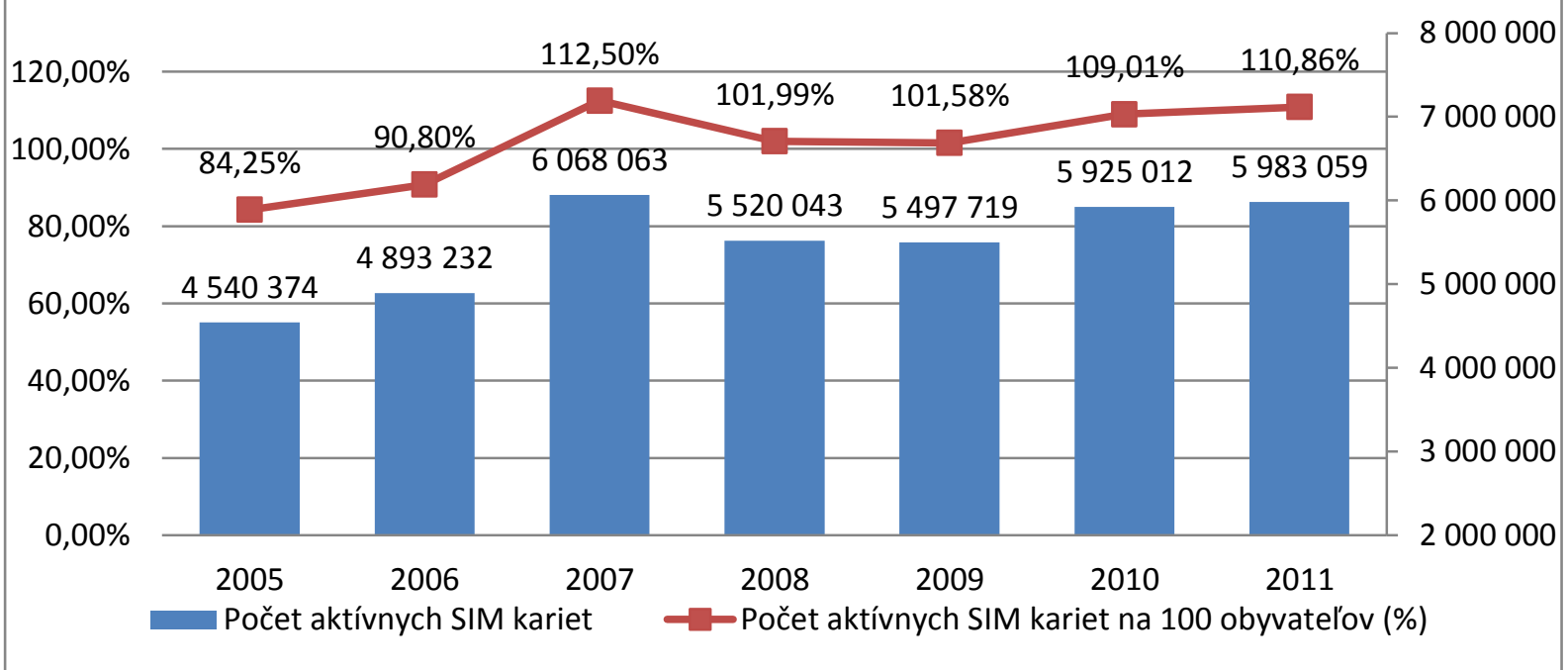

Obrázok 2: Vývoj počtu SIM kariet v mobilnej sieti. (Zdroj: Elektronické komunikácie - vybrané štatistické údaje [online]. [Citované 2012-7-23]. Dostupné na:

http://www.telecom.gov.sk/files/statistika_vus/telekom/index.htm - vlastné spracovanie)

Na obrázku č.2 môžeme vidiet', ako sa menil vývoj počtu aktívnych SIM kariet v mobilnej sieti. Od roku 2005 do roku 2007 bola stúpajúca tendencia SIM kariet. Za toto obdobie vzrástol počet aktívnych SIM kariet o 1527 689. Rok 2007 vykazoval zatial' najvyšší počet SIM kariet na Slovensku. Tento fakt mohol byt' spôsobený dvoma faktormi. Prvým faktorom mohol byt' rôzne finančné a darčekové benefity operátorov, ktoré ponúkali zákazníkom pri zakúpení SIM karty. Druhý faktor, ktorý mohol spôsobit' tento jav je, že v priebehu roka 2008 sa menila metodika vykazovania počtu aktívnych SIM kariet mobilných služieb. Tým pádom sa zmenili podmienky pre zaradenie aktívnych SIM kariet do štatistického vykazovania. Údaj o penetrácii mobilných služieb je vypočítaný na základe porovnatel'nej metodiky, podl'a ktorej sa za aktívneho zákazníka považujú zákazníci predplatených služieb, ktorí na svojej SIM karte za posledné tri mesiace uskutočnili najmenej jednu aktívnu operáciu spolu so zákazníkmi využívajúcimi paušálne služby. Základom pre výpočet penetrácie je počet obyvatel'ov SR na úrovni 5,4 milióna [2]. Pri akceptovaní faktora, zmeny výpočtu metodiky, počtu aktívnych SIM kariet, je od roku 2008 každoročne takisto vykazovaný nárast aktívnych SIM kariet. Za obdobie 4 rokov sa tak zvýšil celkový počet SIM kariet o 463016 a hodnota v roku 2011 predstavovala počet 5983059 aktívnych SIM kariet v mobilnej sieti. Na obrázku č.2 je znázornený aj počet aktívnych SIM kariet na 100 obyvatel'ov. Penetrácia SIM kariet sa prvýkrát dostala nad hranicu $100 \%$ v roku 2007, čo znamená, že od tohto roku je na Slovensku každoročne vykazovaných viac aktívnych SIM kariet, ako je samotný počet obyvatel'ov Slovenska. Vel'mi jednoducho povedané to znamená, 
že priemerne každý obyvatel' vlastní viac ako jednu SIM kartu. Najvyššiu penetráciu opät' zaznamenal rok 2007, kde počet SIM kariet na 100 obyvatel'ov predstavoval hodnotu 112, $50 \%$. Po zmene výpočtu metodiky od roku 2008 táto hodnota mierne klesla, no stále sa držala nad úrovňou $100 \%$. V roku 2011 sa opät' penetrácia aktívnych SIM kariet zvýšila na porovnatel'nú úroveň z roka 2007 a predstavovala hodnotu 110,86\%.

\section{Trh širokopásmového prístupu}

Širokopásmový prístup, je taký druh prístupu k poskytovaným zdrojom a službám, ktorý koncových uživatel'ov podstatným spôsobom neobmedzuje v druhu, obsahu, rozsahu a kvalite požadovanej služby, t.j. ktorý nie je tzv. „úzkym hrdlom“ v celom ret’azci medzi koncovým užívatel'om a poskytovatel'mi služieb a najrôznejšími siet'ovými zdrojmi, a je dostupný nepretržite (minimálna prenosová rýchlost' >256kbit/s., asymetricky pre individuálne pripojenie koncového užívatel'a, alebo $>2 \mathrm{Mbit} / \mathrm{s}$., symetricky pre potreby pripojenia komerčného sektora a verejnú správu). Širokopásmový prístup prináša nové dimenzie poznania a mnoho výhod pre užívatel'a, napríklad:

- zjednodušenie vzájomného kontaktu medzi l’ud’mi, podnikmi, obchodnými spoločnost’ami, verejnou správou a inými organizáciami;

- jednoduchšie a rýchlejšie vyhl'adávanie informácií;

- efektívnejšie riadenie podnikov, hlavne malých a stredných, ktoré vedie k zvýšeniu ich výkonnosti a následne konkurencieschopnosti;

- širokopásmový prístup poskytuje možnost' využívania verejných služieb elektronickou formou, napr.: elektronická verejná správa (e-government), elektronické vzdelávanie (e-learning), elektronické zdravotníctvo (e-health), elektronické podnikanie (ebusiness), elektronické obchodovanie (e-commerce) [3].

$\mathrm{Na}$ súčasnom rozvoji širokopásmového prístupu majú najväčší podiel technológie xDSL, ktoré využívajú existujúcu infraštruktúru metalických káblov pevných telekomunikačných sietí. V súčasnosti trh elektronických komunikácií na Slovensku ponúka širokopásmové pripojenie bud' v pevnej sieti alebo mobilnej sieti.

\section{Širokopásmové pripojenie v pevnej sieti}

Širokopásmové pripojenie v pevnej sietí môže byt' realizované viacerými druhmi technológií. Medzi najznámejšie spôsoby pripojenia patria:

- Digitálna účastnícka prípojka xDSL - znamená širokopásmový prístup cez telefónnu prípojku. Technológie xDSL využívajú na prenos digitálneho signálu symetrické alebo asymetrické vedenia v infraštruktúre metalických káblových vedení, prístupových sietí, pevných verejných telekomunikačných sietí. Technológia xDSL je vyvinutá tak, aby mohla súčasne fungovat' po boku ISDN hlasových služieb. Je to možné vzhl'adom nato, že táto technológia prenáša signály na vyšších frekvenciách, ako používa ISDN. Prenosom signálu na vyšších frekvenciách sa zabezpečí, aby nedochádzalo k prekrývaniu s ISDN technológiou. Tým pádom sa dáta prostredníctvom DSL technológie môžu zasielat' súčasne s hlasom na rovnakom medenom kábli. $\mathrm{V}$ praxi sa najčastejšie využívajú varianty ADSL, ADSL2+, SDSL, VDSL.

- Pevný rádiový prístup (BFWA, WLAN) - považuje sa širokopásmový prístup prostredníctvom rádiového prenosového systému (MVDS, WiMAX, WiFi). Bezdrôtové technológie určené na komunikáciu medzi pevnými bodmi sa vo všeobecnosti označujú ako 
„pevné“. Sú známe pod viacerými názvami ako pevný alebo terestriálny bezdrôtový prístup (FWA alebo WLL). Pevný bezdrôtový prístup použiva frekvenčné pásmo až do $40 \mathrm{GHz}$. Za prekážku v rozvoji využívania pevného bezdrôtového prístupu sa považujú najmä: obmedzená kapacita frekvenčného pásma a nutnost' udel'ovania licencií; riziko vzájomného rušenia pri využívaní nelicencovaných frekvenčných pásiem; pomalá štandardizácia (presadzovanie odlišných záujmov výrobcov zariadení).

- Siete káblovej televízie (CATV) - považuje sa širokopásmový prístup cez rozvody káblovej televízie $\mathrm{s}$ využitím káblového modemu. Siete káblovej televízie CATV boli pôvodne špecifickými siet’ami zameranými len na distribúciu televíznych a rozhlasových signálov. Ich architektúra aj technológia sa výrazne odlišovali od telekomunikačných sietí slúžiacich na poskytovanie hlasových a dátových služieb. Moderné siete CATV sú už vybudované s prevažujúcim podielom optickej časti, ktoré zabezpečujú obojsmernú komunikáciu na rozsiahlejšom území (metropolitné a regionálne siete).

- Optické káblové siete (FTTx) - širokopásmový prístup cez optické káble umožňujúce prakticky neobmedzenú kapacitu, vysokú spol'ahlivost' a kvalitu prenosu. Technológia optických káblov sa presadila ako dominantná technológia chrbticových sietí a výkonných medzinárodných a transkontinentálnych prepojení. Väčšie uplatnenie optiky vo výstavbe miestnych sietí sa oneskorilo najmä z ekonomických dôvodov, pretože návratnost' investičných nákladov si vyžadovala optimálne využitie výkonnosti tejto technológie. Technológie, ktoré využívajú optické siete, umožňujú obojsmerný dátový prenos o rýchlosti $2,5 \mathrm{Gbit} / \mathrm{s}$. Optická prístupová siet' môže byt' dovedená až na pracovisko užívatel'a, môže končit' pri dome alebo $\mathrm{v}$ zóne komplexu budov, odkial' môže pokračovat' napríklad metalickým koaxiálnym káblom alebo symetrickým káblovým vedením $\mathrm{s}$ využitím technológií xDSL.

- Družicový prístup - družicové technológie sa používajú na zabezpečenie širokopásmového prístupu (najmä širokopásmového prístupu $\mathrm{k}$ internetu) $\mathrm{v}$ odl'ahlých regiónoch s nedostatočnou komunikačnou infraštruktúrou. Družicový prístup je v porovnaní $\mathrm{s}$ ostatnými technológiami nákladný a pri obojsmernej komunikácii je potrebné počítat' so značným oneskorením signálu.

- Výhl'adové siete interaktívnej digitálnej TV - považuje sa širokopásmový prístup využivajúci set top box a distribučné energetické siete PLC (širokopásmový prístup $\mathrm{s}$ využitím elektrorozvodných sietí). Technológia širokopásmového prístupu cez rozvody elektrickej energie PLC je zameraná na poskytovanie širokopásmových služieb s využitím existujúcej infraštruktúry disponujúcej vel'kým potenciálom konkurenčnej schopnosti. Prenosové médium signálu tvoria samotné elektrické vedenia, pričom sa počíta s vysokofrekvenčným premostením prvkov rozvodu, ktoré sú pre vysokofrekvenčný signál prekážkou (transformátory, ističe, merače odberu energie). Kontroverznost' myšlienky PLC spočíva $\mathrm{v}$ atraktívnosti využitia už existujúcej infraštruktúry a na druhej strane $\mathrm{v}$ riziku, že tento systém by mohol vyžarovaním svojho signálu vážne narušit' rádiovú komunikáciu [4]. 
Tabul'ka 1: širokopásmové pripojenie v pevnej sieti

\begin{tabular}{|l|l|l|l|l|l|}
\hline Pripojenie podl'a technológie & $\mathbf{2 0 0 7}$ & $\mathbf{2 0 0 8}$ & $\mathbf{2 0 0 9}$ & $\mathbf{2 0 1 0}$ & $\mathbf{2 0 1 1}$ \\
\hline xDSL & 277838 & 336369 & 367723 & 398056 & 404823 \\
\hline Optický prístup FTTH/FTTB & 66649 & 118021 & 177574 & 199787 & 223980 \\
\hline Pevný rádiový prístup & 74639 & 84778 & 147150 & 182166 & 206119 \\
\hline Rozvody káblovej televízie & 51434 & 63806 & 80251 & 94449 & 115796 \\
\hline Prenajatý okruh & 1455 & 1687 & 2174 & 2122 & 2128 \\
\hline Družicový prístup & 5 & 27 & 184 & 373 & 252 \\
\hline
\end{tabular}

*údaje sú uvádzané k 31.12 daného roka (Zdroj: Elektronické komunikácie - vybrané štatistické údaje [online]. [Citované 2012-07-23]. Dostupné na:

http://www.telecom.gov.sk/files/statistika_vus/telekom/index.htm - vlastné spracovanie)

Tabul'ka č.1 poskytuje informácie o stave širokopásmového pripojenia na SR od roku 2007 po rok 2011. Telekomunikačný úrad SR v roku 2011 evidoval 743 telekomunikačných operátorov, ktorí poskytovali širokopásmový internet v SR. Napriek postupnému budovaniu optických sietí sa najviac užívatel'ov pripája $\mathrm{k}$ internetu prostredníctvom technológií xDSL. Koncom roka 2011 sa až 404823 užívatel'ov pripájalo k širokopásmovému internetu prostredníctvom DSL (ADSL alebo ASDSL2+ od Slovak Telekomu a.s., prípadne SHDSL od GTS Slovakia). Druhým najrozšírenejším typom fixného širokopásmového pripojenia bola technológia pomocou optického prístupu, ktorá od roku 2008 každoročne vykazuje viac pripojených užívatel'ov ako bezdrôtové siete WiFi a FWA. Pripojenie pomocou rozvodov káblových televízií takisto zaznamenali vysoký nárast $\mathrm{v}$ roku 2011, kde toto pripojenie využilo 115796 užívatel'ov. Celkovo všetky možné spôsoby širokopásmového pripojenia v pevnej sieti vykazujú od roku 2007 každoročne nárast (s výnimkou družicového prístupu v roku 2011, kde nastal mierny pokles oproti roku 2010).

\section{Širokopásmové pripojenie v mobilnej sieti}

V mobilnej sieti rozlišujeme širokopásmové pripojenie podl'a technológie (3G, FDD, HSDPA, Flash OFDM) alebo rozdelenie podl'a prístupu pripojenia (SIM, USIM, karty, modemy).

3G/FDD - Frequency Division Duplex - prijímač a vysielač operujú na rôznych prenosových frekvenciách.

3G/HSDPA - High-Speed Downlink Packet Access - znamená rýchle st’ahovanie dát, ktorého teoretické maximum je 14,4 Mbit/s. Ide o protokol mobilnej telekomunikácie označovaný tiež ako technológia 3,5G. HSDPA slúži na zvyšovanie prenosovej rýchlosti pre downlink.

Flash OFDM - je skratka z Fast Low-latency Access with Seamless Handoff Orthogonal Frequency Division Multiplexing. Je to jeden $\mathrm{z}$ variantov mobilného širokopásmového internetového prístupu. Prenosové rýchlosti v praxi dosahujú pri optimálnych podmienkach pre jedného používatel'a až 5,3 Mbps (download) / 1,8 Mbps (upload) $\mathrm{v}$ závislosti od kvality a intenzity signálu $\mathrm{v}$ mieste pripojenia a od množstva užívatel'ov v danej oblasti.

SIM/USIM karty - karty, pomocou ktorých je možné pripojenie internetu priamo do mobilného telefónu.

Dátové zariadenia (karty/modemy) - mobilné pripojenie internetu pomocou dátového zariadenia. Pomocou týchto zariadení je možné pripojit’ na internet napríklad notebook alebo PC. 
Tabul'ka 2: Širokopásmové pripojenie v mobilnej sieti

\begin{tabular}{|l|r|r|r|r|r|}
\hline rozdelenie podl'a technológii & $\mathbf{2 0 0 7}$ & $\mathbf{2 0 0 8}$ & $\mathbf{2 0 0 9}$ & $\mathbf{2 0 1 0}$ & $\mathbf{2 0 1 1}$ \\
\hline 3G/FDD & 71263 & 352785 & 511377 & 671455 & 1162040 \\
\hline 3G/HSDXA, Flash OFDM & 121066 & 214718 & 319812 & 457431 & 584366 \\
\hline Rozdelenie podl'a pripojení & & & & & \\
\hline Mobilné telefóny SIM/USIM karty & 192329 & 352687 & 552635 & 771499 & 1358324 \\
\hline Dátové zariadenia (karty/modemy) & - & 214816 & 278554 & 357387 & 388082 \\
\hline
\end{tabular}

*údaje sú uvadzané k 31.12. daného roka Zdroj: (Elektronické komunikácie - vybrané štatistické údaje [online]. [Citované 2012-07-23]. Dostupné na:

http://www.telecom.gov.sk/files/statistika_vus/telekom/index.htm - vlastné spracovanie)

Tabul'ka č.2 nám poskytuje informácie o stave širokopásmového pripojenia v SR v mobilnej sieti. V súčasnosti sa najviac užívatel'ov pripája pomocou technológií širokopásmového mobilného pripojenia. Pripojenie v mobilnej sieti d'aleko prevyšuje pripojenia v pevnej sieti. Najviac využívaná technológia širokopásmového pripojenia v mobilnej sieti v roku 2011 bola technológia 3G/FDD, ktorej pripojenie využilo 162040 užívatel'ov. Táto technológia dosiahla vel'kého rozmachu práve na prelome rokov 2010 a 2011. Všetky mobilné technológie (v pozorovaných rokoch) zaznamenali každoročne nárast. To svedčí o vel'kom potenciáli mobilnej technológie, pomocou ktorej užívatelia využívajú širokopásmové pripojenie.

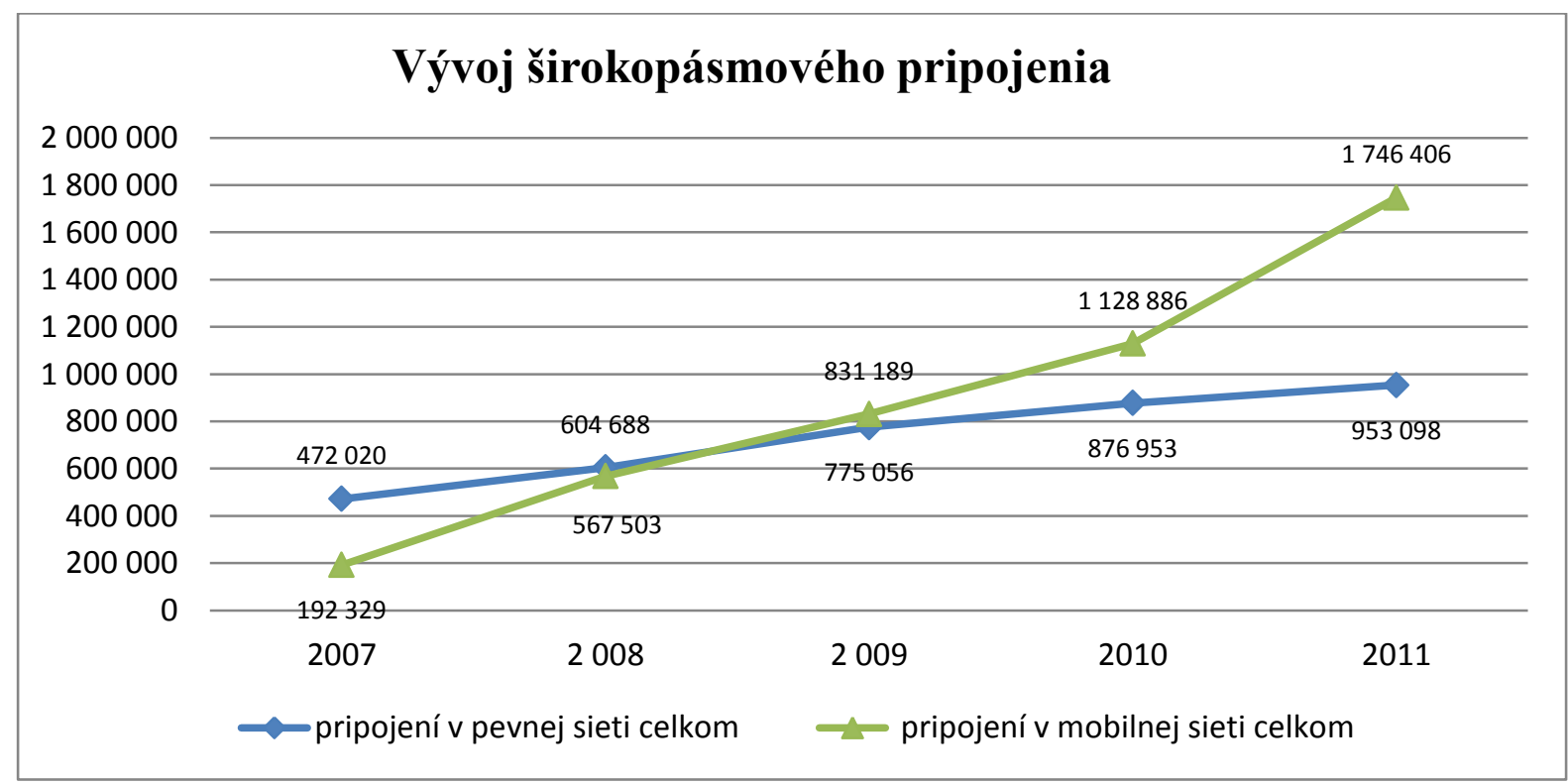

Obrázok 3: Širokopásmové pripojenie v pevnej a mobilnej sieti

*údaje sú uvadzané $\mathbf{k}$ 31.12. daného roka (Zdroj: Elektronické komunikácie - vybrané štatistické údaje [online]. [Citované 2012-07-23]. Dostupné na:

http://www.telecom.gov.sk/files/statistika_vus/telekom/index.htm - vlastné spracovanie)

Obrázok č.4 nám interpretuje celkový počet širokopásmového pripojenia v pevnej a mobilnej sieti. Na obrázku je znázornená zmena, ktorá nastala medzi rokom 2008 a 2009, kde počet širokopásmového mobilného pripojenia predstihol pripojenie v pevnej sieti. S vývojom trhu elektronických komunikácií vzrastajú aj zákaznícke požiadavky. Možnost' byt' zastihnutel'ný kdekol'vek a pripojený kedykol'vek je jedna z hlavných zákazníckych požiadaviek. Preto technológie pripojenia v mobilnej sieti dokážu lepšie uspokojit' zákaznícke požiadavky. Okrem toho rýchlosti pripojenia na internet prostredníctvom mobilných sietí sú porovnatel'né s ponukou v pevných siet'ach, pričom v niektorých prípadoch ich aj prevyšujú. 
Celkový nárast pripojení za obdobie 4 rokov predstavoval hodnotu 1554077 v mobilnej sieti a hodnotu 481079 v pevnej sieti. Čo sa týka penetrácie širokopásmového pripojenia v pevnej sieti na 100 obyvatel'ov, najvyššia hodnota bola zaznamenaná v roku 2011 a predstavovala 17,66\%. Penetrácia pripojenia na 100 obyvatel'ov v mobilnej sieti dosiahla najvyššiu hodnotu takisto v roku 2011 a predstavovala 32,36\%. Celkovo sa dá povedat', že širokopásmový prístup zaznamenáva na Slovensku každoročne niekol'kopercentný nárast.

\section{Záver}

Trh elektronických komunikácií na Slovensku prešiel za posledné roky výraznými zmenami. Do toho trhu sú vkladané vel'ké investície jednak zo strany štátu, ako aj investície zo súkromných sektorov. Postupná liberalizácia a harmonizácia trhu EK predstavuje vidinu jednotného európsky trh elektronických komunikácií, ktorý by jedného dňa mohol byt' dosiahnutý. Dovtedy bude vel'mi zaujímavé sledovat', ako sa bude menit' trh EK na Slovenku a spolu s ním aj jednotlivé čiastkové trhy. Zaujímavé bude sledovat', ako sa „upadajúci trh pevných sietí“ vysporiada s postupných nahradzovaním mobilnými siet’ami a oproti tomu, do akej výšky nastaví ,latku“ trh mobilných sietí.

\section{Použitá literatúra}

[1] SME sk. Počet pevných liniek klesá. [online]. [citované 2012-08-03]. Dostupné na: <http://www.sme.sk/c/3172832/pocet-pevnych-liniek-na-slovenskuklesa.html\#ixzz20yV24EkQ>

[2] Ekonomika SME sk. Aktívnych SIM kariet. [online]. [citované 2012-08-03]. Dostupné na: <http://ekonomika.sme.sk/c/5781661/aktivnych-SIM-kariet-je-na-slovensku-takmer-sestmilionov.html\#ixzz20ypCJkRc>

[3] Význam širokopásmového prístupu na internet. [online]. [citované 2012-08-03]. Dostupné na:

〈www.vus.sk/broadband/nbbs/VUSBB_PPP_SF_11_2006fin.pdf>

[4] Prognóza vývoja sektora EK. [online]. [citované 2012-08-03]. Dostupné na: $<$ http://www.google.sk/url?sa=t\&rct=j\&q=\&esrc $=$ s \& source $=$ web \&cd=2\&ved=0CFIQFj AB\&url=http\%3A\%2F\%2Fwww.telecom.gov.sk\%2Findex\%2Fopen_file.php\%3Ffile\%3 Dtelekom\%2Fvyskum\%2Fprojekty\%2F2005\%2F114.pdf\&ei=UZ0SUIbtGvDS4QTSzY GgDQ\&usg=AFQjCNGgnVduvnGeGuDLZa8wD_uwwI0n7A>

\section{Grantová podpora:}

> 1/KS/2012 inštitucionálny výskum: Analýza citlivosti počtu kontaktných miest $\mathrm{k}$ nákladom plynúcim z poskytovania UPS

> 8/KS/2012 inštitucionálny výskum: Analýza skutočného stavu portfólia a dostupnosti širokopásmových internetových služieb pre vybrané regióny

> 3/KS/2012 inštitucionálny výskum: Podpora vzdelávania pomocou výučbových multimediálnych aplikácií 